\title{
Anadangəlmə unilateral pulmonar ageneziya müşahidəmiz
}

\author{
Nərmin Ozizova ${ }^{1}$ \\ ${ }^{1}$ K. Faracova adına Elmi Tadqiqat Pediatriya Institutu
}

Açar sözlor: neonatal dövr, müalica, pulmonar ageneziya, tədqiqat.

Giriș: Unilateral pulmonar ageneziya nadir rastlanan $(10.000$ - 15.000 yenidoğulandan 1-də) anadangəlmə qüsur olub, yenidoğulanlarda və həyatın sonrak1 dövrlərində aşkar edilir. Yenidoğulan dövrdə daha çox respirator distresə səbəb olur və xəstələrin bir qismi tənəffüs çatışmazlığ 1 ilə həyatını itirirlər. Xəstələrin təqribən yarısında yanaşı olaraq kardiovaskulyar, gastrointestinal və dayaq-hərəkət aparatının anomaliyaları rastlanır. Diaqnoz əsasən komputer tomoqrafiya əsasında qoyulur. Yenidoğulan dövrdə nadir rast gəlinən sağ tərəfli pulmonar ageneziyalı bir klinik müşahidəmizi təqdim edirik.

Xəstə təqdimi: Corrahi yolla keysəriyyə əməliyyatı ilə 39 həftəlik 3250 qr çəki ilə dünyaya gələn oğlan uşağında birinci və beşinci dəqiqələrdə Apqar şkalası altı və səkkiz qeyd edildi. Antenatal ultrasəs aparılmayıb. Doğuşdan iki saat sonra uşaqda göyərmə, inildəmə və interkostal, subkostal retraksiya müşahidə edilib. Uşaq həyatının beşinci günündə klinikamızın reanimasiya şöbəsinə qəbul edilmişdir. Xəstə daxil olarkən vəziyyyəti ağır, süst, adinamik, sianotik olub, əmmə aktı çox zəif idi. Ürək tənəffüs çatışmazlığı (saturasiya $82 \%$, tənəffüs say1 80/dəq, nəbz 160/dəq) əlamətləri qeyd edilib. Körpə küvez rejiminə və noninvaziv mexanik ventilyasiya aparatına qoşuldu. Auskultasiyada sağ hemitoraksda tənəffüs səsləri eşidilməyib və sağ 4-cü qabırğa arası sahədə ürək vurğuları eşidilir. Döş qəfəsi ön proyeksiya rentgenoqramında sağ ağciyərin total atelektaziya və ya hipoplaziyası diaqnozu qoyulub (sağ ağciyərin parenximası izlənmədi). Divararalı̆̆ın soldan sağa doğru tam dislokalizasiyası izlənilir. Traxeya və sol baş bronx izlənilir. Sol ağciyərin kompensator havalılığının atması müşahidə edilir. Plevral sinuslar sərbəstdir (Şəkil 1). KT müayinəsində divararalığı və ürək yerini sağa doğru dəyişmişdir. Sağ hemitoraksda ağciyər parenximasına aid görünüm izlənməmişdir. Sağ ana bronx və sağ pulmonar arteriya izlənməmiş olub, traxeya sol bronx olaraq davam etməkdədir. Sol ağciyər həcmi kompensator olaraq artmışdır. Diaqnoz: sağ ağciyərin total ageneziyası (Şəkil 2,3). Elektrokardioqrammada dekstrakardiya və PDA $2 \mathrm{~mm}$ müşahidə edilir. Həmçinin ultrasəs müayinədə sol xayanın hipoplaziyası qeyd edilir. 3 gün intensiv terapiyadan sonra xəstə kafi vəziyyətdədir: Ps - 138/dəq, tənəffüs sayı 62/dəq və otaq havasinda saturasiyanın $94 \%$.

Nəticə: Sağ tərəfli pulmonar ageneziyada ürək və mediasteniumun yer dəyişməsi ilə birgə böyük damarların distorsiyasının müşahidə edilməsi xəstəliyin gedişinin daha ağır olmasına səbəb olur. Proqnoz əlavo anomaliyaların olub-olmaması va ağciyərin funksional qabiliyyətinə bağlı olaraq dəyişir. Bizim xəstəmizdə pulmonar ageneziya ilə yanaşı ağır anomaliyalar rast gəlinməməsi səbəbi ilə proqnoz daha kafi müşahidə edildi.

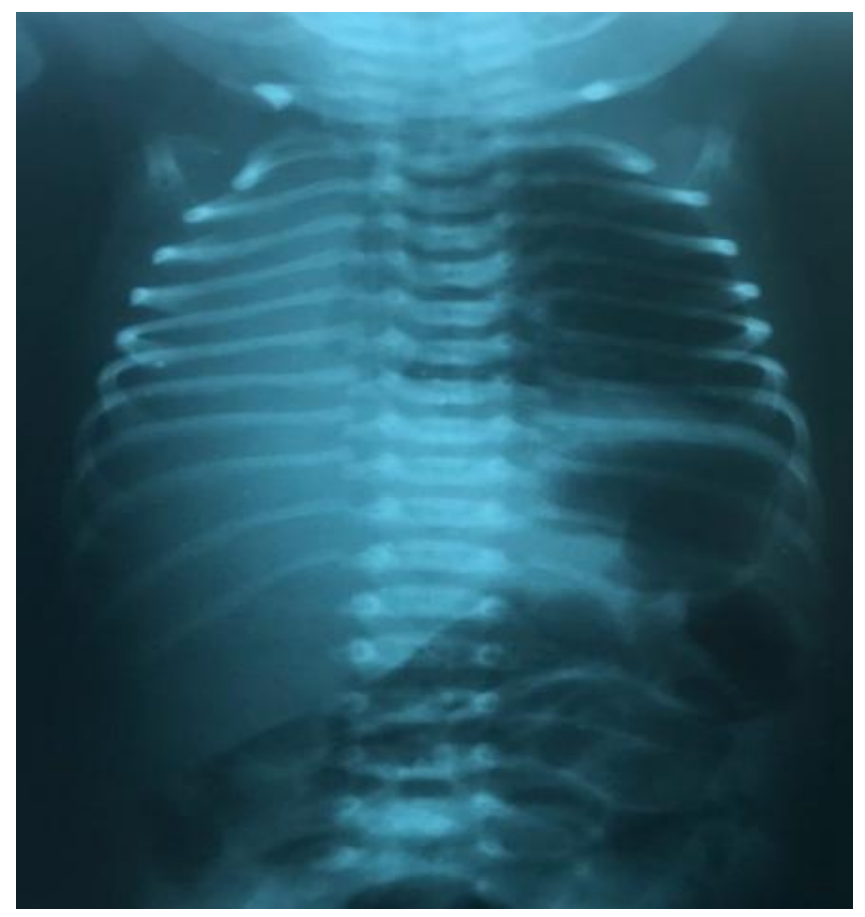



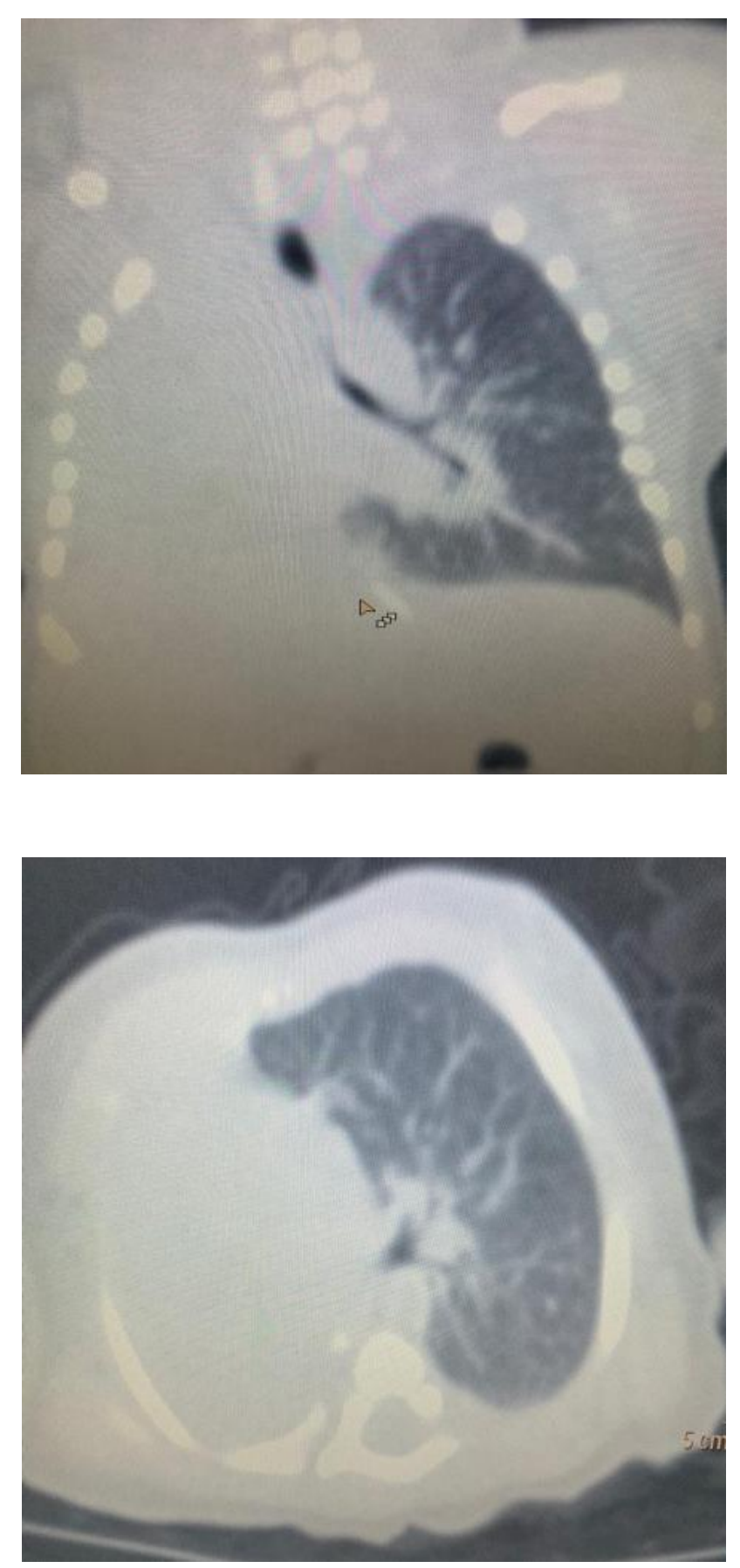

Maliyyə Mənbəyi: Məqalənin hazırlanmasında heç bir kənar maliyyə mənbəyindən istifadə edilməyib.

Maraqların toqquşması: Qeyd edilməyib. 